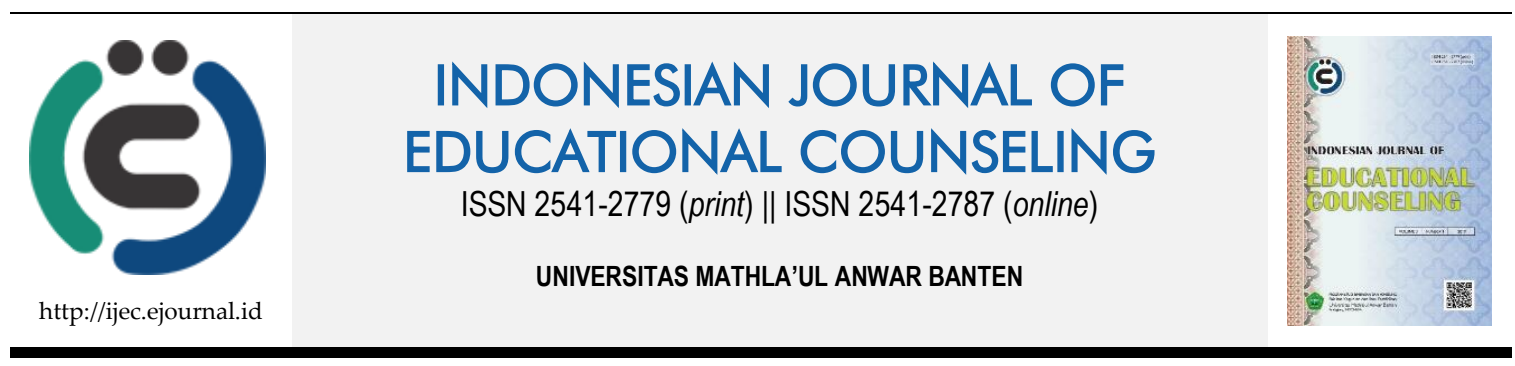

Research Based Article

\title{
Perception Assessment of Guidance and Counseling Services among Educational Stakeholders in Selected Secondary Schools in Oyo State, Nigeria
}

\author{
Muraina Kamilu Olanrewaju' ${ }^{1}$, Yusuf Suleiman² \\ ${ }^{1}$ Legacy University, Gambia, ${ }^{2}$ Unicaf University, Cyprus
}

\begin{tabular}{ll}
\hline Article History & ABSTRACT \\
\hline Received: 10.12.2018 & Guidance and counseling is a service that all human beings need at one point \\
Received in revised form: & of their life. There is no human being that has never got a problem at one point \\
Accepted: 11.02 .2019 & or another. This study focused on the assessment of perception of guidance and \\
Available online: 31.01 .2019 & counseling services among educational stakeholders in selected secondary \\
& schools in Oyo State, Nigeria. Descriptive research design of ex-post-facto type \\
& was used in the study. Simple and purposive sampling techniques were used \\
& in sampling 300 participants from 10 local government areas (50 schools) in Oyo \\
& state. The respondents were measured with validated scale of 0.91 reliability \\
& coefficient and the data obtained was analyzed using simple percentage \\
& statistical analysis. Three (3) research questions were raised and answered. The \\
& results showed that school administrators, teacher and parents (educational \\
& stakeholders) had negative perception of guidance and counseling services. In \\
& view of these findings, the study recommended that educational stakeholders \\
& need guidance in order to understand and appreciate guidance and counseling \\
& services and that parents should be made to realize that the times are fast \\
& changing and that they have to gradually change from the old ways so as to \\
& change positively to guidance and counseling services.
\end{tabular}

Keywords: Educational Stakeholders, Guidance and counseling Services, Perception.

DOI: $10.30653 / 001.201931 .62$

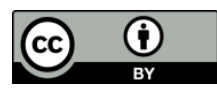

This is an open access article distributed under the terms of the Creative Commons Attribution 4.0 International License, which permits unrestricted use, distribution, and reproduction in any medium, provided the original work is properly cited. (c) 2019 Muraina Kamilu Olanrewaju, Yusuf Suleiman.

\section{INTRODUCTION}

Guidance and counseling is a service that all human beings need at one point of their life. There is no human being that has never got a problem at one point or another. Once a problem arises, one seeks solutions, suggestions or even other people's opinions about the problem. In one way or another, one seeks for guidance and counseling services. Guidance and counseling services are services that have been in existence as long as

${ }^{2}$ Corresponding author's address: Unicaf University, Famagusta Avenue, Larnaca, Cyprus, Ammoxostou, Larnaca 6019, Siprus. Email: y.suleiman@unicaf.org 
human beings have lived, either formally or informally. Guidance and counseling has been engraved in African traditional society since time immemorial. According to Busari (2012), guidance and counseling was entrusted to the immediate and extended family where individuals confined in and depended upon their relatives for advice when faced with problems. As such in the African traditional society, people of all ages could seek for this service from the elderly or respected people in the society such as fortune-tellers, wizards, astrologers, palmists and future-tellers were thought to be getting information from the gods and could therefore guide and counsel others according to what the gods have counseled.

Young people could be counseled by the elderly on the norms of the society and what was expected of them in the society. All this was informal Counseling. However, in the African traditions, the elders counseled the younger ones and the wiser counseled those with less experience. Likewise, the expertise and religious leaders such as Pastor and Imams counseled the whole society (Oderinde \& Muraina, 2014). Man sought comfort, help and solace from the family and close associates. Children were brought up in a neatly woven relationship of the extended family in African Traditional Societies. The society had counselors who included aunts, uncles, and grandparents. However, the home as one avenue of instilling sex and moral education is challenged by modern constraints such as shattered cultural basis of child upbringing, rising standards of living, economic constraints, and inadequate family guidance and counseling, child headed homes, wars, tribal clashes, cattle rustling, displacement and moral conflict (Busari, 2012).

The behaviour according to Popoola (2004) was reinforced through rewards, punishment and taboos and with the coming of western education; young people are not available to be counseled by the elders resulting to erosion of the societal norms and ethics. This called for formal guidance and counseling services in schools where these young people were now to be found. As a result, issues of adolescent sexuality and moral are increasingly being entrusted with the school. Counseling is a helping profession that attempts to help counselees to solve a range of problems that cut across personal and emotional challenges which clients are unable to solve themselves. It is therefore pertinent that practitioners have control over their emotions. The reason is because clients presenting problems usually are emotionally charged. Inability to manage personal emotions can have adverse consequence for counseling outcome (Adeyemo, 2015). The ability to perceive and appropriately interpret the emotions of counselees enhances the likelihood that the goals of counseling would be achieved.

From the conceptual point of view, perception refers to the way one looks at the events happening in an environment. From a technical point of view, it refers to the organization, identification and interpretation of sensory information in order to represent and understand the environment (McAdams \& Schmidt, 2007). Perception depends on complex functions of the nervous system, but subjectively seems mostly effortless because this processing happens outside conscious awareness (Goldstein \& Goldstein, 2009). Guidance and counseling is a professional field which has a broad range of activities and services aimed at assisting individuals to understand themselves, their problems, their school environment and their world (Lunenburg, 2010; Muraina \& Mohammad, 2017). The main policy goal for secondary level education is the provision of resources that would allow all school age children, and others so desiring, to receive and complete a junior high school program of quality. Further, that as many as can benefit as so wish, move on to and complete a diversified broad base high quality senior high school program or its equivalent in readiness for the next stage/phase of living and learning. This study 
therefore examines the assessment perception of guidance and counseling services among educational stakeholders in selected secondary schools in Oyo State, Nigeria. Educational stakeholders in this study include the administrators, teachers as well as the parents.

Administrators are the school personnel in charge of monitoring and supervision of teaching and non-teaching activities in the school system. Fitch, Newby, Ballestero, and Marshall (2001) examined the perceptions of administrators regarding the role of the school counselor. At most schools, the school counselors' role are determined by administrators. Fitch et al (2001) concluded that many misperceptions of the role of the school counselor still exist. As Wagner (1998) expressed, students' needs are better able to be met as a result of collaboration and support among school personnel. Administrators and school counselors often do not agree on the school counselors' roles (Shoffner \& Williamson, 2000). Administrators view the school as an organized whole, whereas counselors view the school as student-centered. School counselors and school principals are trained separately and do not have many opportunities to learn about the responsibilities, roles, and perspectives of each other. The school counselor and principal need to not only discuss the guidance and counseling needs within the school, but they also need to determine how the school counselor can fulfill the needs. Ponec and Brock (2000) also emphasized the importance of evaluating guidance and counseling programs. The evaluation process should be reviewed on a yearly basis, and it should include students, staff, and parents. As a result, it is beneficial to know the criteria that administrators value when selecting school counselors.

Furthermore, principals still believe that counselors should have teaching experience. This may be due to the fact that principals regard counselors as "upgraded teachers" rather than specialists in Counseling (Nugent, 1981). Olson and Allen (1993) examined principals' perceptions of school counselor effectiveness with and without teaching experience. The need for counselors to have prior teaching experience was not supported by this study. For instance, there were no significant differences between principals' perceptions of teacher and non-teacher counselors' ability to effectively conduct guidance lessons. In addition, both teacher and non-teacher counselors equally received positive comments regarding their professionalism and efficiency. Administrators' perception of the school counselors' role is extremely important, and as Fitch et al (2001) reported, misperceptions of the school counselors' role still exist. Therefore, it is imperative to enhance the relationship between school counselors and administrators to aid administrators in developing a better understanding of the roles of the school counselor. Muraina and Mohammad (2017) highlighted the importance of clear communication and support strategies between school counselors and administrators. Shoffner and Williamson (2000) demonstrated that school counselors and administrators develop greater appreciation and respect for one another given the opportunity to discuss their roles, standards, perspectives, and expectations.

Teachers are the personnel that discharge the instructional content to the students in the school. It is not only important for administrators to have an understanding of the school counselors' roles, it is necessary for teachers to understand them as well. Davis and Garrett (1998) stated that teachers' perceptions of the school counselors' role are barriers that prevent school counselors from successfully providing services. Many teachers view the school counselor as someone who sits in his or her office all day drinking coffee, interrupts their class with a note to see a student with little or no explanation, or is another administrator. Consequently, teachers are hesitant to send their students to the counselor for fear of losing valuable instruction time. As Davis and Garrett (1998) explained, their 
reluctance is a legitimate concern for teacher accountability is measured by grades and test scores. However, school counselors rely on teachers for student referrals. Hence, the relationship between the school counselor and teacher is one of importance. Teachers can add valuable insight and often achieve a sense of empowerment when they know that they have the school counselor on their side, working with them to help the student (Muraina \& Mohammad, 2017).

Talking with the teacher can also aid the counselor in determining whether the concern is home-based, school-based, or both. Furthermore, the researchers reported that it is useful for the school counselor to sit in on a class to observe classroom dynamics and student behaviour. They have found that teachers respond well to having the school counselor observe class, for it demonstrates the counselors' commitment to working with the teacher to meet student needs. Oderinde and Muraina (2014) emphasized the importance of enlisting teachers as co-facilitators. Students sometimes feel more comfortable talking with their teachers regarding concerns rather than the school counselor. Muraina and Mohammad (2017) stated that conflict may occur when both school counselors and special education teachers are expected to provide consultation services. Both professionals consult with classroom teachers and parents. Parr (1991) stated that teachers sometimes displace negative feelings towards counselors because they view the counselor as a safer scapegoat to displace their frustration as compared to a principal. Additionally, some teachers envy counselors because they work with individuals and small groups, whereas teachers must manage a large classroom. Also, teachers sometimes expect counselors to work magic. In other words, teachers want the counselor to "fix" a student.

Like administrators and teachers, parents serve as important stakeholders. Unfortunately, Chapman and DeMasi (1991) stated that when budgets are tight, the school counselor position is one of the first things to be cut. Some parents want to end school Counseling and other student-focused programs because they are non-academic, detract from subject instruction, and invade family privacy (Kaplan, 1997). Campbell (1993) stated that many parents have negative associations with regards to school Counseling due to past contact with educators of their children as well as their own school experience. As a result, increased parent awareness of the school counselors' position and services is imperative. However, Orfield and Paul (1994) reported that only 17 percent of parents meet with their student's high school counselor. Nevertheless, parents and school counselors need to collaborate and work together to ensure the best outcome for their students. Muraina and Mohammad (2017) identified reasons why counselors and parents should work together during the college advising process which include lack of knowledge on the current and comprehensive requirement of college admissions, student becoming very confused and conflict may arise when he/she is receiving different information from the school counselor among others.

A study conducted by Chapman and DeMasi (1991) found that the students would have more accurate information on the rate of their contact with the school counselor as compared to their parents. Parent perception of school counselor effectiveness may not be based on accurate assessment of school counselor and student interaction (Oderinde and Muraina, 2014). In general, the majority of parents gave school counselors low ratings on overall effectiveness. Chapman and DeMasi (1991) reported that $90 \%$ of the parents used college advising services offered by the school counselor, but they rated the information that they received from the counselor as moderate. Parents stated that they were somewhat or not at all satisfied with the school counselors' work with their children. 
Evans and Hines (1997) stated that parents' work schedules often make it difficult for them to set and keep appointments. As Kaplan (1997) explained, some parent groups strongly oppose school activities that take time away from academics. Such activities include teacher advisory, homeroom classes, classroom guidance, and school counseling programs.

Guidance counselors as helper in the school identifies and resolves problems through individual and group counseling, interprets test results, assesses children's concerns, makes referrals, and conducts classroom guidance activities. In the consultant role, the school counselor provides professional advice and expertise through classroom assessment, home visits, curriculum planning, and role-playing techniques. Educational stakeholders see counselors as administrative assistants who perform clerical tasks and non-counseling duties, which are not mentally challenging. Furthermore, teachers expressed greater dissatisfaction with the position of counselors compared to administrators. Despite this, research conducted in schools supports the use of Counseling and guidance programs to promote student learning and that guidance and counseling services reinforces emotional and behavioural self-management to improve classroom learning and academic achievement. This study therefore concentrates on the assessment of perception of guidance and counseling services among educational stakeholders in selected secondary schools in Oyo State, Nigeria.

\section{Statement of the Problem}

In Nigeria, reports from the primary, secondary and tertiary educational level point out that the learners are indulging in pleasure and luxury. People have bad manners, contempt for authority, and disrespect for older people. It is not common to hear parents, teachers and church leaders blaming each other, for failing to teach the young people to be well behaved. Many parents have abandoned the teaching of their children which people have entrusted to the counselor. Although the Ministry of Education has ensured that each public school has a teacher-counselor appointed by Teachers Service Commission (TSC) yet indiscipline cases persist and Nigeria is not exceptional. A number of studies have been done on factors influencing implementation of guidance and counseling activities in secondary schools. Also, there has been very little research done in Nigeria in this area especially on the perception of educational stakeholders. In order to fill the gap in the previously conducted studies, the study therefore concentrates on the assessment of perception of guidance and counseling services among educational stakeholders in selected secondary schools in Oyo State, Nigeria.

\section{Purpose of the Study}

The main purpose of this study is to investigate the assessment of perception of guidance and counseling services among educational stakeholders in selected secondary schools in Oyo State, Nigeria. Specifically, other purposes of the study include to: 1) examine the perception level of guidance and counseling services among secondary school administrators; 2) assess the perception level of guidance and counseling services among secondary school teachers; and 3) evaluate the perception level of guidance and counseling services among secondary school parents. 


\section{METHODS}

The study adopted descriptive survey of ex-post-facto approach. Such an approach does not involve the manipulation of variables in the study. It is therefore, after the fact study. It's neither adds to nor subtracts from the existing fact. However, it is carefully observe and record information as it naturally occurred at the time the study was conducted.

\section{Participants}

The participants for the study were all Educational stakeholders in selected secondary schools in Oyo State, Nigeria. Simple random and purposive sampling techniques were used in this study. Ten (10) Local Government Areas (LGAs) were randomly selected out of 33 LGAs in Oyo State. In each randomly selected LGAs, 5 secondary schools were randomly selected. Also, in each randomly selected secondary school, 2 administrators, 2 teachers and 2 parents were purposively selected. On the whole, total numbers of participants selected were 300 and these cut across male and female.

\section{Instrumentation}

A self-developed questionnaire tagged "Perception of Guidance and counseling Services among Educational Stakeholders Scale (PGCSESS) was used to measure the responses of participants. It has 6 items with 2 sections (A-B). Section A consisted of demographic data of the participants while section $B$ dealt with the measure of perception of guidance and counseling services among educational stakeholders. The response format ranges from strongly agree (5), agree (4), undecided (3), disagree (2), strongly disagree (1). For content and face validity of the instruments designed for the study, the researcher gave the instruments to experts in the field of Educational Research and Statistics. After all these people had given their suggestions and made necessary correction on the instrument, the researcher then adjusted them for usage. After content and face validity of the instruments, 10 copies of the instruments were administered in order to re-establish the psychometric properties of the instrument. The test retest analysis of reliability was then used to test their reliability to ensure that they are consistent in measuring what they were designed to measure. The results from the analysis carried out yielded 0.91 which showed that the instrument is valid and reliable for usage.

The instruments were administered to the respondents on the day approved by the school management for the exercise. The researcher was assisted by research assistance in administration and collection of the instruments in translating the instrument to the participants in order to ensure valid responses. In each of selected secondary schools, the administration and collection of instruments were done on the same day of administration. On the whole data collection lasted for 5 weeks.Simple percentage statistical method was used to analyse the data collected in this study.

\section{RESULTS AND DISCUSSION}

The Perception Level of Guidance and Counseling Services among Secondary School Administrators

The respondents were asked to indicate the perception of guidance and counseling services, using a five point scale format of strongly agreed (SA), agreed (A), undecided $(\mathrm{U})$, disagreed (D) and strongly disagreed (SD). 16(16.0\%) of the respondents strongly 
agreed, $12(12.0 \%)$ agreed, $8(8.0 \%)$ undecided, $23(23.0 \%)$ disagreed and $41(41.0 \%)$ strongly disagreed that guidance and counseling services are necessary in the school and $21(21.0 \%)$ of the respondents strongly agreed, $11(11.0 \%)$ agreed, $7(7.0 \%)$ undecided, $21(21.0 \%)$ disagreed and $40(40.0 \%)$ strongly disagreed that there is need to provide guidance and counseling in the areas of career choice and progression. Also, $17(17.0 \%)$ of the respondents strongly agreed, $12(12.0 \%)$ agreed, 10(10.0\%) undecided, $18(18.0 \%)$ disagreed and $43(43.0 \%)$ strongly disagreed that both teachers and students need counseling and guidance in the area of interpersonal relationships and 22(22.0\%) of the respondents strongly agreed, $8(8.0 \%)$ agreed, $9(9.0 \%)$ undecided, 15(15.0\%) disagreed and 46(46.0\%) strongly disagreed that there is need for guidance and counseling services in handling cocurricular activities. However, 19(19.0\%) of the respondents strongly agreed, 10(10.0\%) agreed, $8(8.0 \%)$ undecided, $23(23.0 \%)$ disagreed and $40(40.0 \%)$ strongly disagreed that counseling is considered to be powerful to influence students in doing the right things and $14(14.0 \%)$ of the respondents strongly agreed, $17(17.0 \%)$ agreed, $11(11.0 \%)$ undecided, $22(22.0 \%)$ disagreed and $36(36.0 \%)$ strongly disagreed that guidance and counseling services in schools are likely to improve the students' perception of life. Therefore, the results in table 1 indicated that administrators had negative perception of guidance and counseling services.

Table 1. Perception of guidance and counseling services among secondary schools administrators

\begin{tabular}{|c|c|c|c|c|c|c|c|c|c|c|c|}
\hline S/N & Items & SA & $\%$ & A & $\%$ & U & $\%$ & $\mathrm{D}$ & $\%$ & SD & $\%$ \\
\hline 1. & $\begin{array}{l}\text { Guidance and counseling } \\
\text { services are necessary in this } \\
\text { school }\end{array}$ & 16 & 16.0 & 12 & 12.0 & 8 & 8.0 & 23 & 23.0 & 41 & 41.0 \\
\hline 2. & $\begin{array}{l}\text { There is need to provide } \\
\text { guidance and counseling in the } \\
\text { areas of career choice and } \\
\text { progression }\end{array}$ & 21 & 21.0 & 11 & 11.0 & 7 & 7.0 & 21 & 21.0 & 40 & 40.0 \\
\hline 3. & $\begin{array}{l}\text { Both teachers and students } \\
\text { need Counseling and guidance } \\
\text { in the area of interpersonal } \\
\text { relationships }\end{array}$ & 17 & 17.0 & 12 & 12.0 & 10 & 10.0 & 18 & 18.0 & 43 & 43.0 \\
\hline 4. & $\begin{array}{l}\text { There is need for guidance and } \\
\text { counseling services in handling } \\
\text { co-curricular activities }\end{array}$ & 22 & 22.0 & 8 & 8.0 & 9 & 9.0 & 15 & 15.0 & 46 & 46.0 \\
\hline 5. & $\begin{array}{l}\text { Counseling is considered to be } \\
\text { powerful to influence students } \\
\text { in doing the right things }\end{array}$ & 19 & 19.0 & 10 & 10.0 & 8 & 8.0 & 23 & 23.0 & 40 & 40.0 \\
\hline 6. & $\begin{array}{l}\text { Guidance and counseling } \\
\text { services in schools are likely to } \\
\text { improve the students' } \\
\text { perception of life }\end{array}$ & 14 & 14.0 & 17 & 17.0 & 11 & 11.0 & 22 & 22.0 & 36 & 36.0 \\
\hline
\end{tabular}

\section{The Perception Level of Guidance and Counseling Services among Secondary School Teachers}

The respondents were asked to indicate the perception of guidance and counseling services, using a 5 point scale format of strongly agreed (SA), agreed (A), undecided (U), disagreed (D) and strongly disagreed (SD). $15(15.0 \%)$ of the respondents strongly agreed, $11(11.0 \%)$ agreed, $10(10.0 \%)$ undecided, $22(22.0 \%)$ disagreed and $42(42.0 \%)$ strongly disagreed that guidance and counseling services are necessary in the school and 22(22.0\%) of the respondents strongly agreed, 12(12.0\%) agreed, 5(5.0\%) undecided, 22(22.0\%) disagreed and $39(39.0 \%)$ strongly disagreed that there is need to provide guidance and counseling in the areas of career choice and progression. Also, $18(18.0 \%)$ of the respondents strongly agreed, $13(13.0 \%)$ agreed, $8(8.0 \%)$ undecided, $18(18.0 \%)$ disagreed 
and $43(43.0 \%)$ strongly disagreed that both teachers and students need Counseling and guidance in the area of interpersonal relationships and $23(23.0 \%)$ of the respondents strongly agreed, 7(7.0\%) agreed, 9(9.0\%) undecided, 17(17.0\%) disagreed and 44(44.0\%) strongly disagreed that there is need for guidance and counseling services in handling cocurricular activities. However, 17(17.0\%) of the respondents strongly agreed, 11(11.0\%) agreed, $10(10.0 \%)$ undecided, $22(22.0 \%)$ disagreed and $40(40.0 \%)$ strongly disagreed that Counseling is considered to be powerful to influence students in doing the right things and $15(15.0 \%)$ of the respondents strongly agreed, $18(18.0 \%)$ agreed, $11(11.0 \%)$ undecided, $20(20.0 \%)$ disagreed and $36(36.0 \%)$ strongly disagreed that guidance and counseling services in schools are likely to improve the students' perception of life. Therefore, the results in table 2 indicated that teachers had negative perception of guidance and counseling services.

Table 2. Perception of guidance and counseling services among secondary schools teachers

\begin{tabular}{|c|c|c|c|c|c|c|c|c|c|c|c|}
\hline$S / N$ & Items & SA & $\%$ & A & $\%$ & U & $\%$ & D & $\%$ & SD & $\%$ \\
\hline 1. & $\begin{array}{l}\text { Guidance and counseling services } \\
\text { are necessary in this school }\end{array}$ & 15 & 15.0 & 11 & 11.0 & 10 & 10.0 & 22 & 22.0 & 42 & 42.0 \\
\hline 2. & $\begin{array}{l}\text { There is need to provide guidance } \\
\text { and counseling in the areas of } \\
\text { career choice and progression }\end{array}$ & 22 & 22.0 & 12 & 12.0 & 5 & 5.0 & 22 & 22.0 & 39 & 39.0 \\
\hline 3. & $\begin{array}{l}\text { Both teachers and students need } \\
\text { Counseling and guidance in the } \\
\text { area of interpersonal relationships }\end{array}$ & 18 & 18.0 & 13 & 13.0 & 8 & 8.0 & 18 & 18.0 & 43 & 43.0 \\
\hline 4. & $\begin{array}{l}\text { There is need for guidance and } \\
\text { counseling services in handling } \\
\text { co-curricular activities }\end{array}$ & 23 & 23.0 & 7 & 7.0 & 9 & 9.0 & 17 & 17.0 & 44 & 44.0 \\
\hline 5. & $\begin{array}{l}\text { Counseling is considered to be } \\
\text { powerful to influence students in } \\
\text { doing the right things }\end{array}$ & 17 & 17.0 & 11 & 11.0 & 10 & 10.0 & 22 & 22.0 & 40 & 40.0 \\
\hline 6. & $\begin{array}{l}\text { Guidance and counseling services } \\
\text { in schools are likely to improve } \\
\text { the students' perception of life }\end{array}$ & 15 & 15.0 & 18 & 18.0 & 11 & 11.0 & 20 & 20.0 & 36 & 36.0 \\
\hline
\end{tabular}

\section{The Perception Level of Guidance and counseling Services among Secondary School Parents}

The respondents were asked to indicate the perception of guidance and counseling services, using a 5 point scale format of strongly agreed (SA), agreed (A), undecided (U), disagreed (D) and strongly disagreed (SD). 16(16.0\%) of the respondents strongly agreed, $12(12.0 \%)$ agreed, $10(10.0 \%)$ undecided, $20(20.0 \%)$ disagreed and $42(42.0 \%)$ strongly disagreed that guidance and counseling services are necessary in the school and $23(23.0 \%)$ of the respondents strongly agreed, $13(13.0 \%)$ agreed, $7(7.0 \%)$ undecided, $20(20.0 \%)$ disagreed and $37(37.0 \%)$ strongly disagreed that there is need to provide guidance and counseling in the areas of career choice and progression. Also, 19(19.0\%) of the respondents strongly agreed, $14(14.0 \%)$ agreed, $10(10.0 \%)$ undecided, $17(17.0 \%)$ disagreed and $41(41.0 \%)$ strongly disagreed that both teachers and students need counseling and guidance in the area of interpersonal relationships and 25(25.0\%) of the respondents strongly agreed, $8(8.0 \%)$ agreed, $9(9.0 \%)$ undecided, $18(18.0 \%)$ disagreed and $40(40.0 \%)$ strongly disagreed that there is need for guidance and counseling services in handling cocurricular activities. However, $18(18.0 \%)$ of the respondents strongly agreed, 12(12.0\%) agreed, $11(11.0 \%)$ undecided, 22(22.0\%) disagreed and 37(37.0\%) strongly disagreed that counseling is considered to be powerful to influence students in doing the right things and $17(17.0 \%)$ of the respondents strongly agreed, $18(18.0 \%)$ agreed, $12(12.0 \%)$ undecided, $20(20.0 \%)$ disagreed and $33(33.0 \%)$ strongly disagreed that guidance and counseling 
services in schools are likely to improve the students' perception of life. Therefore, the results in table 3 indicated that parents had negative perception of guidance and counseling services.

Table 3. Perception of guidance and counseling services among secondary schools Parents

\begin{tabular}{|c|c|c|c|c|c|c|c|c|c|c|c|}
\hline S/N & Items & SA & $\%$ & $\mathrm{~A}$ & $\%$ & $\bar{U}$ & $\%$ & $\bar{D}$ & $\%$ & SD & $\%$ \\
\hline 1. & $\begin{array}{l}\text { Guidance and counseling services } \\
\text { are necessary in this school }\end{array}$ & 16 & 16.0 & 12 & 12.0 & 10 & 10.0 & 20 & 20.0 & 42 & 42.0 \\
\hline 2. & $\begin{array}{l}\text { There is need to provide guidance } \\
\text { and counseling in the areas of } \\
\text { career choice and progression }\end{array}$ & 23 & 23.0 & 13 & 13.0 & 7 & 7.0 & 20 & 20.0 & 37 & 37.0 \\
\hline 3. & $\begin{array}{l}\text { Both teachers and students need } \\
\text { Counseling and guidance in the } \\
\text { area of interpersonal relationships }\end{array}$ & 19 & 19.0 & 14 & 14.0 & 10 & 10.0 & 17 & 17.0 & 41 & 41.0 \\
\hline 4. & $\begin{array}{l}\text { There is need for guidance and } \\
\text { counseling services in handling } \\
\text { co-curricular activities }\end{array}$ & 25 & 25.0 & 8 & 8.0 & 9 & 9.0 & 18 & 18.0 & 40 & 40.0 \\
\hline 5. & $\begin{array}{l}\text { Counseling is considered to be } \\
\text { powerful to influence students in } \\
\text { doing the right things }\end{array}$ & 18 & 18.0 & 12 & 12.0 & 11 & 11.0 & 22 & 22.0 & 37 & 37.0 \\
\hline 6. & $\begin{array}{l}\text { Guidance and counseling services } \\
\text { in schools are likely to improve } \\
\text { the students' perception of life }\end{array}$ & 17 & 17.0 & 18 & 18.0 & 12 & 12.0 & 20 & 20.0 & 33 & 33.0 \\
\hline
\end{tabular}

The results in table 1 indicated that administrators had negative perception of guidance and counseling services. This is in line with the finding of Fitch et al (2001) who found that many misperceptions of the role of the school counselor still exist. Administrators and school counselors often do not agree on the school counselors' roles (Shoffner and Williamson, 2000). Administrators view the school as an organized whole, whereas counselors view the school as student-centered. Ponec and Brock (2000) also emphasized the importance of evaluating guidance and counseling programs. The evaluation process should be reviewed on a yearly basis, and it should include students, staff, and parents. As a result, it is beneficial to know the criteria that administrators value when selecting school counselors. Furthermore, principals still believe that counselors should have teaching experience. This may be due to the fact that principals regard counselors as "upgraded teachers" rather than specialists in counseling (Nugent, 1981). Olson and Allen (1993) examined principals' perceptions of school counselor effectiveness with and without teaching experience. Muraina and Mohammad (2017) highlighted the importance of clear communication and support strategies between school counselors and administrators.

The results in table 2 indicated that teachers had negative perception of guidance and counseling services. This is in collaboration with the finding of Davis and Garrett (1998) who found that teachers' perceptions of the school counselors' role are barriers that prevent school counselors from successfully providing services. Many teachers view the school counselor as someone who sits in his or her office all day drinking coffee, interrupts their class with a note to see a student with little or no explanation, or is another administrator. Consequently, teachers are hesitant to send their students to the counselor for fear of losing valuable instruction time. Davis and Garrett (1998) explained, their reluctance is a legitimate concern for teacher accountability is measured by grades and test scores. However, school counselors rely on teachers for student referrals. Muraina and Mohammad (2017) emphasized the importance of enlisting teachers as co-facilitators. Students sometimes feel more comfortable talking with their teachers regarding concerns rather than the school counselor. Oderinde and Muraina (2014) stated that conflict may 
occur when both school counselors and special education teachers are expected to provide consultation services. Parr (1991) stated that teachers sometimes displace negative feelings towards counselors because they view the counselor as a safer scapegoat to displace their frustration as compared to a principal. Additionally, some teachers envy counselors because they work with individuals and small groups, whereas teachers must manage a large classroom.

The results in table 3 indicated that parents had negative perception of guidance and counseling services. This supported the finding of Chapman and DeMasi (1991) who stated that when budgets are tight, the school counselor position is one of the first things to be cut. Some parents want to end school counseling and other student-focused programs because they are non-academic, detract from subject instruction, and invade family privacy (Kaplan, 1997). Campbell (1993) stated that many parents have negative associations with regards to school counseling due to past contact with educators of their children as well as their own school experience. As a result, increased parent awareness of the school counselors' position and services is imperative. However, Chapman and DeMasi (1991) identified reasons why counselors and parents should work together during the college advising process which include lack of knowledge on the current and comprehensive requirement of college admissions, student becoming very confused and conflict may arise when he/she is receiving different information from the school counselor among others. Parent perception of school counselor effectiveness may not be based on accurate assessment of school counselor and student interaction (Oderinde and Muraina, 2014). Parents stated that they were somewhat or not at all satisfied with the school counselors' work with their children. However, they were more positive about the school counselors' overall contribution to the school's educational program (Chapman and DeMasi, 1991). Evans and Hines (1997) stated that parents' work schedules often make it difficult for them to set and keep appointments.

\section{CONCLUSIONS}

Based on the findings of this study, the high level of negative perception of guidance and counseling services among educational stakeholders need not to continue indefinitely in Nigeria. The participants' perceptions indicated personal barriers, and knowledge gaps on guidance and counseling services among educational stakeholders. The study maintains that in order to avert greater catastrophe more than what is being experienced in Nigeria today as a result of laxity on the part of the major stakeholders in the education sector, all hands must be on deck. The school counselor is a consultant, collaborator, and colleague, as well as an ally who understands the demands of the classroom. They serve as a source of information when making decisions. Furthermore, teachers are vital in integrating affective, humanistic education into the curriculum. They are the "fast-line" helpers in the counseling program. As stated above in this study, teachers provide counselors with student referrals and comprehensive profiles. Clearly, school counseling programs are unsuccessful without the support and acceptance of teachers. Many school counselors create parent counseling committees that meet monthly with the school counseling department in order to collaborate on projects that benefit the school. The parents on the counseling committee become school counseling advocates who educate uniformed parents. A parent can e-mail the school counselor with a concern about his/her son or daughter. The counselor can respond with a few suggestions of how to help the problem and with resources that the parent can use to assist their child. 


\section{REFERENCES}

Adeyemo, D. A. (2015). Enhancing professionalism in counselling through skills development. Journal of Counselling and Human Developmental Studies, 5(2), 1-22.

Busari, A. O. (2012). Essential guidance and counselling practices. Mokola, Ibadan: Gbemisola Multiservice Publisher.

Campbell, C. (1993). Strategies for reducing parent resistance to consultation in the schools. Elementary School Guidance \& Counseling, 28(2), 83-91.

Chapman, D. W., \& DeMasi, M. (1991). Parents' perceptions of the effectiveness of public school counsellors in college advising. School Counsellor, 38(4), 268-278.

Conroy, E., \& Mayer, S. (1994). Strategies for consulting with parents. Elementary School Guidance \& Counseling, 29(1), 60-66.

Davis, K. M., \& Garrett, M. T. (1998). Bridging the gap between school counselors and teachers: A proactive approach. Professional School Counseling, 1(5), 54-55.

Evans, J. E., \& Hines, P. L. (1997). Lunch with school counselors: Reaching parents through their workplace. Professional School Counseling, 1(2), 45-47.

Fitch, T., Newby, E., Ballestero, V., \& Marshall, J. L. (2001). Future school administrators' perceptions of the school counselor's role. Counselor Education and Supervision, 41(2), 89-99.

Goldstein, M. C., \& Goldstein, M. A. (2009). Food and nutrition controversies today: A reference guide. California: ABC-CLIO.

Idol, L., \& Baran, S. (1992). Elementary school counselors and special educators consulting together: Perilous pitfalls or opportunities to collaborate?. Elementary School Guidance $\mathcal{E}$ Counseling, 26(3), 202-213.

Kaplan, L. S. (1997). Parents' rights: Are school counselors at risk?. The School Counselor, 44(5), 334-343.

Lunenburg, F. C. (2010). School guidance and counselling services. Schooling, 1(1), 1-9.

McAdams, C., \& Schmidt, C. (2007). How to help a bully: Recommendations for counseling the proactive aggressor. Professional School Counseling, 11(2), 120-128.

Muraina, K. O., \& Mohammad, B. H. (2017). Solution-focused psychotherapy and self-efficacy in enhancing professional competence of secondary school counsellors in Gombe State, Nigeria. Being a paper Presented at 42nd CASSON International Conference held at Awka between Monday 21st to Friday 25th August, 2017

Nugent, F. A. (1981). Professional counseling: An overview. Monterey, CA: Brooks/Cole. 
Oderinde, O. I., \& Muraina, K .O. (2014). Professional development and experience as determinants of counselling perceived effectiveness among selected school counsellors in Southwestern, Nigeria. International Journal of Research on Humanities and Social Sciences, 4(24), 1-7.

Olson, M. J., \& Allen, D. N. (1993). Principals' perceptions of the effectiveness of school counselors with and without teaching experience. Counselor Education and Supervision, 33(1), 10-21.

Orfield, G., \& Paul, F. (1994). High hopes, long odds: A major report on Hoosier teens and the American dream. Indianapolis, IN: Indiana Youth Institute.

Parr, G. D. (1991). Dilemmas in the workplace of elementary school counselors: Coping strategies. Elementary School Guidance \& Counseling, 25(3), 220-226.

Ponec, D. L., \& Brock, B. L. (2000). Relationships among elementary school counselors and principals: A unique bond. Professional School Counseling, 3(3), 208-217.

Popoola, B. I. (2004). Correlates of School Counsellor Effectiveness in South Western Nigeria. Journal of Social Sciences, 8(3), 237-243.

Shoffner, M. F., \& Williamson, R. D. (2000). Engaging preservice school counselors and principals in dialogue and collaboration. Counselor Education and Supervision, 40(2), 128-140.

Wagner, T. (1998). Change as collaborative inquiry: A constructivist methodology for reinventing schools. Phi Delta Kappan, 79(7), 512. 